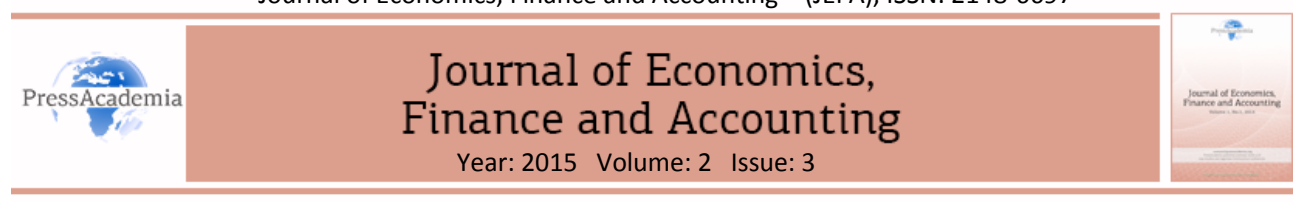

\title{
AUDITOR ROTATION AT BORSA ISTANBUL FIRMS: AN EVENT STUDY
}

\section{DOI: 10.17261/Pressacademia.2015312962}

\author{
Emrah Arioglu', Koray Tuan² \\ ${ }^{1}$ Cukurova University. earioglu@cu.edu.tr \\ ${ }^{2}$ Cukurova University. ktuan@cu.edu.tr
}

\section{Keywords \\ Auditing, auditor rotation, auditor reputation, Borsa Istanbul.}

\section{JEL Classification} M32, M49

\begin{abstract}
This study investigates the market reaction surrounding the announcements of audit firm rotation by public firms quoted at BIST. In addition, it investigates how the market reaction to audit firm rotation changes based on the reputation of the previous and the new audit firms. After conducting an event study, we are unable to provide evidence suggesting that investors in Turkish capital markets value audit firm rotation. The market reaction surrounding the announcements of public firms to switch audit firms or to renew their contracts with the current audit firms is not statistically significant. Our findings also suggest that investors in Turkish capital markets do not value the reputation of audit firms when public firms switch auditors as well. The results are robust to various event windows and alternative audit firm reputation definitions.
\end{abstract}

\section{INTRODUCTION}

Mandatory auditor rotation for public firms is a widely debated topic in the US and the European Union, as well as in Turkey. As a result of the attempts to improve the transparency of corporate practices and the quality of corporate governance applications in capital markets, public firms in Turkey are currently subject to mandatory auditor rotation. No matter if it is audit firms or auditors that are subject to rotation, there is no consensus that the benefits of mandatory rotation would outweigh the costs, or vice versa in the literature. In this study we investigate auditor rotation from the point of view of market participants: we investigate how investors in Turkey react to audit firm rotation in public firms. Unfortunately, the number of firms that have changed audit firms as a result of legal requirements is very limited at Borsa Istanbul (BIST) since the mandatory auditor rotation has been effective only recently. Therefore, in this study we investigate the market reaction to audit firm rotation in public firms even if the rotation is not mandatory.

We believe that our results could provide valuable insight into understanding whether or not investors in Turkish capital markets value auditor rotation and can contribute to the arguments regarding whether or not mandatory auditor rotation will benefit shareholders as a result of potential increases in firm value. Due to structural differences and the corporate practices in emerging markets, the benefits expected to be gained from 
mandatory auditor rotation in developed countries might not be achieved in an emerging economy. Therefore, our findings could be useful not only in the case of auditor rotation but also regarding any future arguments about imposing legal requirements, which help improve firm value in developed countries, on Turkish public firms. After all, as a result of differences in investor behavior, a requirement that benefit shareholders in the US could potentially be costly for investors in Turkish capital markets.

The main goal of this study is to investigate the market reaction surrounding the announcements of audit firm rotation by public firms quoted at BIST. In addition, we investigate the market reaction to announcements in which firms announce that they will be audited by the same audit firm as the previous year. If investors believe that the potential benefits of audit firm rotation would outweigh potential costs, we would expect to observe significantly higher market reaction to audit firm rotation announcements. Indeed, market participants might not value every audit firm rotation decision at the same level. It is possible that they might favor some rotation decisions compared to others. Therefore, we also investigate whether the market reaction changes based various audit firm characteristics that could potentially affect audit quality, such as whether or not the audit firm is an international firm, whether or not it is one of the Big 4 audit firms, and the ranking of the audit firm among all audit firms. We could expect that if firms switch to audit firms that are expected to increase the quality of financial reporting as a result of improved audit quality, markets would react positively to these audit firm changes. Before we present our findings, we briefly discuss why these issues would matter for investors.

The issue of auditor rotation has become widely debated following the accounting scandals at the beginning of the last decade. Accounting irregularities and fraudulent financial reporting led to the questioning of the credibility of independent audit profession, which is an important mechanism that could help reduce the potential agency conflicts between companies and small investors (Blouin et al., 2007). This is possible via improved transparency and by letting investors be informed about whether management acts in a manner that would protect their rights. However, if auditors build such relationships with the firms they audit that they act in the benefit of these firms at the expense of small shareholders, this could destroy firm value. A potential remedy against such a situation is auditor rotation.

Nonetheless, switching to a new auditor is not cost-free. First of all, when a firm's financial reports are being audited by a new audit firm, this would bring some costs to the firm as a result of costs that would arise while the new auditor becomes familiar with the functioning of the firm's operations and systems as well as accounting issues and reporting practices. In addition, selecting the new auditor could also be time consuming when the firm picks an auditor from a pool of potential audit firms (Blouin et al., 2007). Lastly, the decision to switch bears a potential risk of audit failure since the new auditor could be expected to rely too much on firm's estimates due to lack of experience with the audited firm's practices as well as the industry that the firm operates in (Myers et al., 2003; Carcello and Nagy, 2004; Blouin et al., 2007; Kim and Yi, 2009; Skinner and Srinivasan, 2012). Maletta and Wright (1996), and Beasley et al. (2000) provide evidence highlighting the importance of experience in terms of audit quality. 
On the other hand, auditor rotation could provide shareholders of a firm with potential benefits if the quality of financial reporting increases as a result of the auditor switch. First of all, improved transparency could potentially lead to decreased agency costs between shareholders and the firm if it leads to financial reporting quality improvements. Blouin et al. (2007) show that firms are more likely to switch auditors if they bear greater agency costs, whereas firms they are more likely to continue with previous auditors if they bear substantial switching costs.

More importantly, auditor rotation could have a positive effect on firm value as a result of improved auditor independence. It could prevent firms and auditors building such long term relationships that could negatively affect auditor independence in a manner that it would be costly for shareholders. Auditor independence could be expected to lead to improved financial reporting quality (Myers et al., 2003), which could prevent the firm from being involved in fraudulent behavior and consequent law suits and fees. Therefore, auditor rotation could help firms improve audit quality based on the argument that extended auditor tenure could impair the quality of auditing as a result of decreased auditor independence (Carcello and Nagy, 2004). This could result in audit firms supporting management towards more aggressive accounting choices (Myers et al., 2003).

On the other hand, one could alternatively argue that auditor independence would not necessarily be impaired as a result of longer auditor tenure since auditors would have economics incentives that would motivate them to protect their reputation as independent auditors (Reynolds and Francis, 2001; Firth et al., 2012). Lastly, it should be kept in mind that, mandatory auditor rotation could prevent audit firms to state a favorable audit decision in an attempt to keep their contract with companies that they audit, as it could potentially be the case in a voluntary audit firm rotation environment (Vanstraelen, 2000).

In addition to the independence arguments, it could also be argued that as the tenure of audit firms increases, auditors might begin to count on the financial reporting skills of managers of firms as a result of favorable past relationships with these managers' reports. However, new audit firms might be more skeptic with the accounting and reporting practices of firms (Carcello and Nagy, 2004).

In empirical studies, researchers provide mixed results. For example, studies such as Johnson et al. (2002), Carcello and Nagy (2004), Ghosh and Moon (2005), and Chen et al. (2008) show that financial reporting quality does not worsen with longer auditor tenure and that it even improves. However Vanstraelen (2000) shows that the length of auditor tenure could have negative effects on audit quality. On the other hand, Blouin et al. (2007) and Cameran et al. (2015) provide evidence suggesting that mandatory auditor rotation does not necessarily improve financial reporting quality, whereas Krishnan et al. (2007) show that the positive effects of mandatory auditor rotation might depend on the characteristics of the firm that is audited. Studies such as Nagy (2005), Cahan and Zhang (2006), and Kim and Yi (2009) provide evidence suggesting that mandatory auditor rotation could lead to improved financial reporting or auditing quality. 
Based on these arguments and empirical evidence, one could expect to observe a positive market reaction surrounding the announcements of audit firm changes if investors believe that potential benefits of auditor rotation such as improved independence would outweigh any potential costs of switching audit firms.

In addition to the market reaction surrounding audit firm rotation, we also investigate how the market reaction changes based on the reputation of the new audit firm in comparison to the previous audit firm. Audit firms would be expected to have incentives to perform effective auditing to keep their reputations since the firms they audit and the shareholders of these firms would be expected to value auditing of high quality (Weber et al., 2007). If audit firms cannot protect their reputations as effective auditors, their clients would potentially switch to new audit firms (Skinner and Srinivasan, 2012) to protect their reputations for reporting financial statements that are credible (Barton, 2010). Indeed, firms would consider the potential benefits and costs of such switches as we mentioned earlier.

From the point of view of investors, it is not possible to directly observe the quality of the financial statements of firms. Alternatively, they would rely on the reputation of the audit firm that would potentially signal the quality of these statements (Barton, 2010). In support of this argument, studies such as Menon and Williams (1994), Baber et al. (1995), Chaney and Philipich (2002), Krishnamurty et al. (2006), and Cahan et al. (2009) show that markets value the reputation of audit firms, and auditor reputation is reflected to stock prices of audited firms.

Motivated by the arguments and empirical evidence regarding auditor reputation, we investigate whether or not investors in Turkish capital markets value audit firm reputation. One could expect to observe higher market reaction surrounding audit firm switches from less reputable ones to more reputable ones.

Before we proceed, it should be noted that even though a limited number of studies investigate auditor rotation in Turkish capital markets (Arslan, 2011; Karakoc, 2013; Balsari and Varan, 2014; Senyigit and Zeytinoglu, 2014; Akdogan et al., 2015; Yasar, 2015), our study is the first one (to our best knowledge) to study the issue from the point of view of investors in Turkish capital markets.

\section{DATA AND METHODOLOGY}

We investigate the market reaction surrounding audit firm rotation announcements by public firms quoted at Borsa Istanbul between January 2012 and July 2014. Our sample includes 69 audit firm rotation announcements as well as 400 announcements of decisions to renew contracts with current audit firms. Audit firm contract renewal and rotation announcements were gathered from the Public Disclosure Platform (PDP) via reading all the announcements submitted to the PDP. Other data were collected from official data distributers of the BIST such as Finnet and İş Yatırım, in addition to the official webpage of the BIST. Since we employ the 4 Factor Model (4FM) to estimate expected returns and test the significance of abnormal returns, we excluded announcements by financial firms from the sample. In order to prevent the effects of confounding events, we included only 
isolated announcements. In other words, if firm X submitted another announcement to the PDP on the day that it announced the decision to change or renew the audit firm, this announcement was not included in the sample.

In order to estimate expected returns that are required for abnormal return (AR), cumulative abnormal return (CAR) and cumulative average abnormal return (CAAR) calculations, we used the 4FM of Carhart (1997), as opposed to previous studies that investigate market reaction surrounding various corporate events in Turkish capital markets. For a detailed discussion of the expected return estimation models employed in previous studies, readers should consult Basdas and Oran (2014).

The 4FM developed by Carhart (1997) adds the momentum factor that captures the momentum anomaly documented in Jegadeesh and Titman (1993) into the 3 factor model of Fama and French (1993). This model is widely employed in event studies conducted on developed economies and is praised for generating less skewed abnormal returns compared to less complicated expected return estimation models (Ahern, 2009). The 4FM can be stated as below:

$$
R_{i(m)}-R f_{(m)}=a_{i}+b_{i}\left(R M_{(m)}-R f_{(m)}\right)+s_{i} S M B_{(m)}+h_{i} H M L_{(m)}+m_{i} M O M_{(m)}+e_{i(m)}
$$

where RMs denote the average daily returns for all the firms quoted at BIST. In addition, RFs denote the daily risk-free rates of returns. By using this model and the coefficients derived from it, we estimate the expected returns for each stock in our sample. Next, abnormal returns are calculated as the difference between realized returns and expected returns for each firm's stock. This procedure is repeated for each firm in the sample. Then, we use the ARs to calculate the CARs and CAARs over various event windows for robustness purposes. 240 previous trading days, that do not coincide with the event window (Ahern, 2009), are used as the estimation window when calculating estimated returns (Falato et al., 2014). To investigate the market reaction to various announcements abnormal returns (ARs), average abnormal returns (AARs), and cumulative average abnormal returns (CAARs) are required. These can be denoted as:

$$
C A A R_{T}=\underset{\mathrm{t}=1}{\stackrel{\mathrm{T}}{\mathrm{T}}} A A R_{t}
$$

where,

$$
A A R_{t}=\frac{1}{N} \stackrel{\mathrm{a}}{i=1}_{i=1}^{N} A R_{i, t}
$$

and,

$$
A R_{i, t}=R_{i, t}-E\left(R_{i, t}\right)
$$

The significance of CAARs, which are our main measures of interest, are tested via the parametric cross sectional t-test and Boehmer, Musumeci and Poulsen (BMP) tests and the non-parametric sign test. The t-tests that we utilized for these significance tests can be stated as below: 


$$
\begin{array}{ll}
t_{C A A R}=\sqrt{N} \frac{C A A R}{S_{C A A R}} & \text { Cross Sectional t-test } \\
Z_{B M P}=\sqrt{N} \frac{\overline{S C A R}}{S_{\overline{S C A R}}} & \text { BMP test } \\
t_{\text {sign }}=\sqrt{N} \frac{p-0.5}{\sqrt{0.5(1-0.5)}} & \text { Sign test }
\end{array}
$$

These test statistics are used to test whether or not CAARs are statistically significantly different from zero. Next, we present our findings.

\section{EMPIRICAL FINDINGS}

Our findings regarding the market reaction to the announcements to switch audit firms or renew audit contracts with current audit firms are presented in Table 1. The Table shows that the CAAR on the day of the announcements to switch audit firms is $-0.33 \%$. As the event window extends to three and ten days, the CAARs become $-0.06 \%$ and $-1.13 \%$. Even though these CAARs are negative, which could be considered as suggesting that markets react negatively when firms switch audit firms possibly as a result of potential switching costs, the fact that none of the CAARs are statistically significant does not support such a claim.

On the other hand, the Table shows that the CAARs on the announcement days and the three and ten days surrounding the announcements regarding contract renewal with current audit firms are $0.11 \%, 0.19 \%$ and $0.01 \%$, respectively. The CAARs are positive, which could be interpreted as markets valuing the experience of audit firms with current clients or not being worried by auditor independence being compromised. However, once again, they are not statistically significant. In addition, we compare the CAARs between auditor rotation and auditor renewal sub-samples are observe that the CAARs are not statistically significantly different from each other, suggesting that markets do not value the decisions to switch audit firms highly or unfavorably compared to the decisions to renew contract with audit firms. 
Table 1: Auditor Appointment

\begin{tabular}{|c|c|c|c|c|c|}
\hline & $\begin{array}{r}\text { CAAR } \\
(0) \\
\end{array}$ & $\begin{array}{r}\text { Number of } \\
\text { Events }\end{array}$ & $\begin{array}{r}\text { Cross-Sect. } \\
\text { t-test }\end{array}$ & $\begin{array}{r}\text { BMP } \\
\text { t-test }\end{array}$ & $\begin{array}{l}\text { Sign } \\
\text { Test }\end{array}$ \\
\hline Auditor Rotation & $-0.335 \%$ & 69 & -1.09 & -1.06 & -1.32 \\
\hline \multirow[t]{2}{*}{ Renewal-No Rotation } & $0.118 \%$ & 400 & 1.00 & 1.12 & -1.10 \\
\hline & $\begin{array}{r}\text { CAAR } \\
(-1,+1) \\
\end{array}$ & $\begin{array}{r}\text { Number of } \\
\text { Events }\end{array}$ & $\begin{array}{r}\text { Cross-Sect. } \\
\text { t-test }\end{array}$ & $\begin{array}{r}\text { BMP } \\
\text { t-test }\end{array}$ & $\begin{array}{l}\text { Sign } \\
\text { Test } \\
\end{array}$ \\
\hline Auditor Rotation & $-0.061 \%$ & 69 & -0.09 & 0.14 & -0.60 \\
\hline \multirow[t]{2}{*}{ Renewal-No Rotation } & $0.199 \%$ & 400 & 0.91 & 1.03 & -0.50 \\
\hline & $\begin{array}{r}\text { CAAR } \\
(-5,+5)\end{array}$ & $\begin{array}{r}\text { Number of } \\
\text { Events }\end{array}$ & $\begin{array}{r}\text { Cross-Sect. } \\
\text { t-test }\end{array}$ & $\begin{array}{c}\text { BMP } \\
\text { t-test }\end{array}$ & $\begin{array}{l}\text { Sign } \\
\text { Test }\end{array}$ \\
\hline Auditor Rotation & $-1.136 \%$ & 69 & -0.85 & -0.49 & -0.12 \\
\hline Renewal-No Rotation & $0.015 \%$ & 400 & 0.03 & 0.30 & -1.60 \\
\hline
\end{tabular}

The CAARs are compared for auditor renewal and rotation subgroups. The significance levels based on Wilcoxon signed-rank tests are reported. $*, * *$, and $* * *$ present significance at $10 \%, 5 \%$, and $1 \%$ levels.

Overall, based on the evidence presented in Table 1, one cannot suggest that investors in Turkish capital markets value the potential benefits of audit firm rotation such as enhanced audit firm independence, higher than its potential costs such as switching costs and the audit firm lacking experience and familiarity with audited firms. Yet, investors do not appear to react to audit firm switch decisions with the belief that the potential costs would outweigh the benefits, either. It seems that for investors this issue basically does not matter.

On the other hand, it is also possible that markets would value who the new audit firms are in instances of audit firm rotations since they could potentially value firms' being audited by reputable audit firms higher than other less reputable firms. Therefore, we next investigate whether the market reaction based on the reputation differences between the previous and new audit firms in audit firm rotation decision to shed light onto this issue. If audit firm reputation matters, we would expect to observe significantly positive market reaction surrounding the decisions to switch to audit firms with higher reputation from audit firms with lower reputation, and vice versa.

To proxy for auditor reputation, we use whether or not the audit firm is a Big 4 audit firm, whether or not it is an international audit firm, and the ranking of the audit firm among all audit firms based on the number of firms it audits and its revenue. We utilize the official webpages of audit firms in our sample and the webpage of the Capital Markets Board of Turkey in order to identify which audit firms are in the Big 4 group and which ones are domestic branches of international audit firms. In addition, the audit firm ranking data is derived from the list presented in Fortune magazine (Fortune, February 2014). 
Table 2: Auditor Change: International Partnership vs. No International Partnership

\begin{tabular}{|c|c|c|c|c|c|}
\hline & $\begin{array}{r}\text { CAAR } \\
(0) \\
\end{array}$ & $\begin{array}{r}\text { \# of } \\
\text { Events }\end{array}$ & $\begin{array}{r}\text { Cross-S. } \\
\text { t-test }\end{array}$ & $\begin{array}{r}\text { BMP } \\
\text { t-test }\end{array}$ & $\begin{array}{l}\text { Sign } \\
\text { Test }\end{array}$ \\
\hline Domestic to International & $-0.712 \%$ & 7 & -0.70 & -0.45 & -0.37 \\
\hline International to Domestic & $1.533 \%$ & 4 & 0.57 & 0.50 & 0.00 \\
\hline \multirow[t]{2}{*}{ No Change in Internationality } & $-0.327 \%$ & 54 & -0.12 & -1.34 & -1.36 \\
\hline & $\begin{array}{r}\text { CAAR } \\
(0)\end{array}$ & $\begin{array}{r}\text { \# of } \\
\text { Events }\end{array}$ & $\begin{array}{r}\text { Cross-S. } \\
\text { t-test }\end{array}$ & $\begin{array}{l}\text { BMP } \\
\text { t-test }\end{array}$ & $\begin{array}{l}\text { Sign } \\
\text { Test }\end{array}$ \\
\hline Domestic to International & $-1.701 \%$ & 7 & -1.49 & -1.39 & -1.13 \\
\hline International to Domestic & $2.561 \%$ & 4 & 0.51 & 0.46 & -1.00 \\
\hline \multirow[t]{2}{*}{ No Change in Internationality } & $0.435 \%$ & 54 & 0.93 & 0.83 & 0.00 \\
\hline & $\begin{array}{r}\text { CAAR } \\
(0)\end{array}$ & $\begin{array}{r}\text { \# of } \\
\text { Events }\end{array}$ & $\begin{array}{r}\text { Cross-S. } \\
\text { t-test }\end{array}$ & $\begin{array}{c}\text { BMP } \\
\text { t-test }\end{array}$ & $\begin{array}{l}\text { Sign } \\
\text { Test }\end{array}$ \\
\hline Domestic to International & $-0.727 \%$ & 7 & -0.30 & -0.12 & 0.37 \\
\hline International to Domestic & $0.096 \%$ & 4 & 0.02 & 0.05 & 0.00 \\
\hline No Change in Internationality & $-0.098 \%$ & 54 & -0.13 & 0.18 & -0.54 \\
\hline
\end{tabular}

In Table 2, we present the CAARs surrounding audit firm switches based on whether the audit firm is a branch of an international audit company or not. One could argue that an audit firm that is the branch of an international audit company could provide more effective auditing due to the experience of the international audit company. Yet, the opponents of this argument could argue that these international audit companies could lack country-specific experience and knowledge. However, the proponents could argue that such worries are unnecessary since international audit firms do not conduct audits themselves.

Table 3: Auditor Change: BIG4 versus Non-BIG4

\begin{tabular}{lrrrrr}
\hline & $\begin{array}{r}\text { CAAR } \\
(\mathbf{0})\end{array}$ & $\begin{array}{r}\text { \# of } \\
\text { Events }\end{array}$ & $\begin{array}{r}\text { Cross-S. } \\
\text { t-test }\end{array}$ & $\begin{array}{r}\text { BMP } \\
\text { t-test }\end{array}$ & $\begin{array}{r}\text { Sign } \\
\text { Test }\end{array}$ \\
\cline { 2 - 6 } Non BIG4 to BIG4 & $-0.351 \%$ & 8 & -0.67 & -0.96 & 0.00 \\
BIG4 to Non-BIG4 & $-0.953 \%$ & 12 & -1.05 & -1.27 & -1.15 \\
Stable & $-0.051 \%$ & 45 & -0.15 & 0.01 & -1.04 \\
\hline & CAAR & $\#$ of & Cross-S. & BMP & Sign \\
& $(\mathbf{0})$ & Events & t-test & t-test & Test \\
\cline { 2 - 6 } Non BIG4 to BIG4 & $-0.332 \%$ & 8 & -0.50 & -0.73 & 0.00 \\
BIG4 to Non-BIG4 & $0.609 \%$ & 12 & 0.49 & 0.42 & -1.15 \\
Stable & $0.382 \%$ & 45 & 0.60 & 0.73 & -0.14 \\
\hline & CAAR & $\#$ of & Cross-S. & BMP & Sign \\
& $(0)$ & Events & t-test & t-test & Test \\
Non BIG4 to BIG4 & $1.868 \%$ & 8 & 0.90 & 0.45 & 0.00 \\
BIG4 to Non-BIG4 & $0.050 \%$ & 12 & 0.04 & 0.56 & 0.00 \\
Stable & $-0.568 \%$ & 45 & -0.64 & -0.22 & -0.44 \\
\hline
\end{tabular}


Unfortunately, the number of observations is very limited for firms that switch from an international audit firm to a domestic firm, and vice versa. Therefore, it would not be healthy to draw any conclusions based on these CAARs. Nonetheless, the CAARs suggest that market reaction to auditor switches based on audit firms' internationality is not statistically significant.

In Table 3, we present the CAARs based on whether or not audit firms are in Big 4 or not. The Table shows that the CAARs surrounding the announcements of firms to switch from an audit firm that is not in Big 4 to an audit firm that is in Big 4 are $-0.35 \%$ and $-0.33 \%$ on the announcement day and the three days surrounding the announcements. However, one could expect the opposite in terms of the signs of the CAARs if investors in Turkish capital markets were to believe that an audit firm with a higher reputation could perform more effective auditing. Still, it should be kept in mind that the CAARs are not statistically significant.

On the other hand, the CAAR on the announcement day for a firm switching from an audit firm that is in Big 4 to a non-Big 4 audit firm is $-0.95 \%$. This is in line with the auditor reputation arguments. However, the CAAR for the three days surrounding similar announcements is $0.60 \%$, which contradicts the arguments regarding the importance of auditor reputation. Yet neither of these CAARs is statistically significant. In addition, the Table shows that the CAAR for the ten days surrounding the announcements of switches from non-Big 4 to Big 4 audit firms are $1.86 \%$ in support of auditor reputation arguments and the CAAR for the switches the other way around is $0.05 \%$. Once again, none of these CAARs are statistically significant. In addition, as the event window extends, the possibility of confounding events could be pronounced econometrically.

Table 4: Auditor Change: Revenue Based Reputation Ranking

\begin{tabular}{lrrrrr}
\hline & $\begin{array}{r}\text { CAAR } \\
\mathbf{( 0 )}\end{array}$ & $\begin{array}{r}\text { \# of } \\
\text { Events }\end{array}$ & $\begin{array}{r}\text { Cross-S. } \\
\text { t-test }\end{array}$ & $\begin{array}{r}\text { BMP } \\
\text { t-test }\end{array}$ & $\begin{array}{r}\text { Sign } \\
\text { Test }\end{array}$ \\
\cline { 2 - 6 } Reputation Improvement & $-0.384 \%$ & 20 & -0.59 & -0.47 & 0.44 \\
Reputation Decline & $-0.423 \%$ & 25 & -0.98 & -1.24 & -1.80 \\
No Change in Reputation & $-0.202 \%$ & 24 & -0.36 & -0.36 & -0.81 \\
\hline & CAAR & \# of & Cross-S. & BMP & Sign \\
& $\mathbf{( 0 )}$ & Events & t-test & t-test & Test \\
\cline { 2 - 6 } Reputation Improvement & $0.759 \%$ & 20 & 0.92 & 0.95 & 0.44 \\
Reputation Decline & $-1.350 \%$ & 25 & -1.18 & -1.43 & -0.60 \\
No Change in Reputation & $0.597 \%$ & 24 & 0.53 & 0.64 & -0.81 \\
\hline & CAAR & $\#$ of & Cross-S. & BMP & Sign \\
& $\mathbf{( 0 )}$ & Events & t-test & t-test & Test \\
Reputation Improvement & $0.495 \%$ & 20 & 0.38 & 0.29 & -0.44 \\
Reputation Decline & $-2.537 \%$ & 25 & -0.76 & -0.47 & 0.20 \\
No Change in Reputation & $-1.035 \%$ & 24 & -0.79 & -0.60 & 0.00 \\
\hline
\end{tabular}


Lastly, we present findings regarding the market reaction surrounding the auditor switch decisions based on the ranking of audit firms among all audit firms in Turkey. The Table shows that the CAAR on the announcement day is $-0.38 \%$ when a firm switches from a less reputable audit firm to a more reputable audit firm. Once again, this observation contradicts the arguments about the importance of auditor reputation. However, the CAARs for announcements about auditor reputation improvements as a result of audit firm switches are $0.75 \%$ and $0.49 \%$, respectively, which is supportive of auditor reputation arguments. Unfortunately, none of these 3 CAARs are statistically significant.

In addition, the Table shows that when a firm announces a switch from a more reputable audit firm to a less reputable audit firm based on its ranking among all audit firms, markets react negatively to these announcements, supporting the arguments that auditor reputation would matter. However, the statistical significance of these CAARs, which are $0.42 \%,-1.35 \%$ and $-2.53 \%$ respectively, do not support these arguments.

The overall evidence presented in Table 2, Table 3 and Table 4 suggest that investors in Turkish capital markets do not value the reputation of audit firms when their clients switch auditors. These findings contradict the findings of previous studies that investigate the importance of audit firm reputation from the point of view of investors in more developed markets (Menon and Williams, 1994; Baber et al., 1995; Chaney and Philipich, 2002; Krishnamurty et al., 2006; Cahan et al., 2009). This supports our previous arguments suggesting that due to structural differences and the corporate practices in emerging markets, potential benefits of mandatory auditor rotation in developed countries might not be achieved or valued in an emerging economy.

\section{CONCLUSION}

This study investigates the market reaction surrounding the announcements of audit firm rotation by public firms quoted at BIST. In addition, it investigates how the market reaction to audit firm rotation changes based on the reputation of the previous and the new audit firms. We are unable to provide evidence suggesting that investors in Turkish capital markets value the potential benefits of audit firm rotation higher than its potential costs. In addition, investors do not appear to believe that the costs would outweigh the benefits, either. Overall, one cannot suggest that investors in Turkish capital markets value audit firm rotation. Our findings also suggest that investors in Turkish capital markets do not value the reputation of audit firms when public firms switch auditors.

The fact that Turkey is an emerging market is an important factor when interpreting our findings. As discussed in Kim and Yi (2009), due to the structure of the markets and common ownership structures of public firms, audit firms might lack the necessary incentives to perform their duties efficiently. In addition, managers might lack the incentives to demand independent auditing that is of superior quality. It is possible that markets are skeptic about the validity of information presented in financial statements and audit reports on these financial statements. After all, in cultures where personal 
relationships are more valuable, auditors could be selected based on these relationships and could be more influenced by pressures from the clients (Kim and Yi, 2009).

On the other hand, policymakers should assess the potential costs and benefits of mandatory auditor rotation very carefully. If researchers could provide sufficient further evidence suggesting that the benefits of long-term relationships between audit firms and public companies would benefit shareholders highly, they could even consider revoking the imposition on public firms to rotate audit firms.

Future studies investigating the issue of audit firm rotation could investigate the potential effects of the choice for audit firms on firms' stock performances. In addition, they could investigate the relationship between the choice of audit firm and the likelihood of instances of fraudulent behavior or law suits that their clients face. However, such studies should carefully consider the issue of endogeneity. In other words, they should be careful in identifying whether the choice of audit firm affects fraudulent behavior or whether the potential of any fraudulent behavior leads firms to switch auditors.

\section{REFERENCES}

Ahern, K. (2009), Sample Selection and Event Study Estimation, Journal of Empirical Finance, 16, p.466-482.

Akdogan, N., Aktas, M., Gulhan, O. (2015), Borsa İstanbul'da Bağımsız Denetim Şirketleri ve Bağımsız Denetim Görüşleri Üzerine Bir İnceleme, Muhasebe Bilim Dünyası Dergisi, 17(1), p.19-32.

Arslan, E. (2011), Yeni Türk Ticaret Kanunu’na Göre “Denetçinin” Niteliği, Mali Çözüm Dergisi, 104, p.73-107.

Baber, W., Kumar, K., Verghese, T. (1995), Client Security Price Reactions to the Laventhol and Horwarth Bankruptcy, Journal of Accounting Research, 33(2), p.385-395.

Balsari, C. K., Varan, S. (2014), Kaliteli Finansal Raporlamada Denetimin Rolü ile İlgili Tartışmalar, Mali Çözüm Dergisi, 124, p.69-90.

Barton, J. (2010), Who Cares about Auditor Reputation?, Contemporary Accounting Research, 22(3), p.549-586.

Basdas, U., Oran, A. (2014), Event Studies in Turkey, Borsa Istanbul Review, 14(3), p.167-188.

Beasley, M., Carcello, J., Hermanson, D., Lapides, P. (2000), Fraudulent Financial Reporting: Consideration of Industry Traits and Corporate Governance Mechanisms, Accounting Horizons, 14(4), p.441-454.

Blouin, J., Grein, B. M., Rountree, B. (2007), An Analysis of Forced Auditor Change: The Case of Former Arthur Andersen Clients, The Accounting Review, 82(3), p.621-650.

Cahan, S., Zhang, W. (2006), After Enron: Auditor Conservatism and Ex-Andersen Clients, The Accounting Review, 81(1), p.49-82.

Cahan, S., Emanuel, D., Sun, J. (2009), Are the Reputations of the Large Accounting Firms Really International? Evidence from Andersen-Enron Affair, Auditing: A Journal of Practice \& Theory, 28(2), p.199-226.

Cameran, M., Francis, J., Marra, A., Pettiniccho, A. (2015), Are There Adverse Consequences of Mandatory Auditor Rotation? Evidence from the Italian Experience, Auditing: A Journal of Practice \& Theory, 34(1), p.1-24.

Carcello, J., Nagy, A. (2004), Audit Firm Tenure and Fraudulent Financial Reporting, Auditing: A Journal of Practice \& Theory, 23(2), p.55-69.

Carhart, M. (1997), On the Persistence in Mutual Fund Performance, The Journal of Finance, 52(1), p.57-82.

Chaney, P., Philipich, K. (2002), Shredded Reputation: The Cost of Audit Failure, Journal of Accounting Research, 40(4), p.1221-1246. 
Chen, C., Lin, C., Lin, Y. (2008), Audit Partner Tenure, Audit Firm Tenure, and Discretionary Accruals: Does Long Auditor Tenure Impair Earnings Quality?, Contemporary Accounting Research, 25(2), p.415-445.

Falato, A., Kadyrzhanova, D., Lel, U. (2014), Distracted Directors: Does Board Busyness Hurt Shareholder Value?, Journal of Financial Economics, 113, p.404-426.

Fama, E., French, K. (1993), Common Risk Factors in the Returns on Stocks and Bonds, Journal of Financial Economics, 33, p.3-56.

Firth, M., Rui, O., Wu, X. (2012), How Do Various Forms of Auditor Rotation Affect Audit Quality? Evidence from China, The International Journal of Accounting, 47(1), p.109-138.

Ghosh, A., Moon, D. (2005), Auditor Tenure and Perceptions of Audit Quality, The Account Review, 80(2), p.585612.

Jegadeesh, N., Titman, S. (1993), Returns to Buying Winners and Selling Losers: Implications for Stock Market Efficiency, The Journal of Finance, 48(1), p.65-91.

Johnson, V., Khurana, I., Reynolds, K. (2002), Audit-firm Tenure and the Quality of Financial Reports, Contemporary Accounting Research, 19(4), p.637-660.

Karakoc, M. (2013), Türk Ticaret Kanunu ile Birlikte Bağımsız Denetimde Meydana Gelen Gelişmeler, Muhasabe ve Finansman Dergisi, 59, p.17-38.

Kim, J., Yi, C. H. (2009), Does Auditor Designation by the Regulatory Authority Improve Audit Quality? Evidence from Korea, Journal of Accounting and Public Policy, 28(3), p.207-230.

Krishnamurthy, S., Zhou, J., Zhou, N. (2006), Auditor Reputation, Auditor Independence, and the Stock Market Impact of Andersen's Indictment on Its Client Firms, Contemporary Accounting Research, 23(2), p.465-490.

Krishnan, J., Raghunandan, K., Yang, J. S. (2007), Were Former Andersen Clients Treated More Leniently the Other Clients? Evidence from Going-concern Modified Audit Opinions, Accounting Horizons, 21(4), p.423-435.

Maletta, M., Wright, A. (1996), Audit Evidence Planning: An Examination of Industry Error Characteristics, Auditing: A Journal of Practice \& Theory, 15(1), p.71-86.

Menon, K., Williams, D. (1994), The Insurance Hypothesis and Market Prices, The Accounting Review, 69, p.327342.

Myers, J. N., Myers, L. A., Omer, T. C. (2003), Exploring the Term of the Auditor-client Relationship and the Quality of Earnings: A Case for Mandatory Auditor Rotation?, The Accounting Review, 78(3), p.779-799.

Nagy, A. L. (2005), Mandatory Audit Firm Turnover, Financial Reporting Quality, and Client Bargaining Power: The Case of Arthur Andersen, Accounting Horizons, 19(2), p.51-68.

Reynolds, J. K., Francis, J. (2001), Does Size Matter? The Influence of Large Clients on Office-level Auditor Reporting Decisions, Journal of Accounting and Economics, 30(3), p.375-400.

Senyigit, Y. B., Zeytinoglu, E. (2014), Zorunlu Denetçi Rotasyonunun Denetim Kalitesi Üzerindeki Etkileri: Literatür Araştırması, İstanbul Üniversitesi İşletme Fakültesi İşletme İktisadı Enstitüsü Yönetim Dergisi, 77, p.79-98.

Skinner, D. J., Srinivasan, S. (2012), Audit Quality and Auditor Reputation: Evidence from Japan, The Accounting Review, 87(5), p.1737-1765.

Vanstraelen, A. (2000), Impact of Renewable Long Term Audit Mandates on Audit Quality, The European Accounting Review, 9(3), p.419-442

Weber, J., Willenborg, M., Zhang, J. (2008), Does Auditor Reputation Matter? The Case of KPMG Germany and ComROAD AG, Journal of Accounting Research, 46(4), p.941-972.

Yasar, A. (2015), Olumsuz Denetim Görüşü ve Bağımsız Denetçi Değişikliği Arasındaki İlişki: Borsa İstanbul Sanayi Şirketleri Üzerine Bir Uygulama, Muhasabe ve Finansman Dergisi, 65, p.81-96. 